\title{
Women's Poetry and The Sexual Politics of Babel
}

\author{
Karen Van Dyck
}

In this article I explore the connection between babble and Babel, two states of language which accentuate deterritorialization, that is the foreign and unempowered status of the writing or speaking subject. ${ }^{1}$ By babble I mean the confusion within one language usually associated with infants who have not yet mastered the language, or a Cassandra figure who has lost control of the language. By Babel I mean the confusion caused by a multitude of different languages and the problems of translation that ensue. Although the Oxford English Dictionary in its definition of "babble" reports that it cannot trace any direct connection with Babel, it does admit that "association with that may have affected the senses." In the popular imagination both babble and Babel are seen as nuisances, posing as they do the impossibility of one to one equivalencies between words and things. It is this similarity that prompts me to consider how the specific babble of recent women's poetry in Greece might provide some insights into the more general question of Babel and translation which critics from Roman Jakobson to Walter Benjamin to Jacques Derrida have analyzed.'

In a larger work I trace the ellipticism of recent women's poetryin particular Rea Galanaki's, Jenny Mastoraki's and Maria Laina'sback to the seven-year dictatorship which ended in 1974 (Van Dyck 1990). My hypothesis is that what began more generally as a ploy for evading censorship under the dictatorship actually became a distinguishing feature of women's poetry after the regime's fall. While most poets, with the lifting of censorship, assumed that poetry could speak clearly again and say what it meant, women poets continued to write poetry that was difficult to decipher. This babble, initially marginalized, or doubly marginalized, if we consider modern Greek literature's own marginal status in relation to other major literatures, has, in the 1980 s, slowly begun to gain recognition as a viable alternative writing style. Let us first examine how women's poetry turned its minor status Journal of Modern Greek Studies, Volume 8, 1990. 
into an empowering strategy of resistance, and then what its various styles of deterritorialization might teach us about translation more generally.

\section{Women's Poetry and Deterritorialization}

For centuries "good" women poets were thought to have "risen above" their gender. The term "yuvalkzí $\alpha \rho \alpha \varphi$ n" [women's writing] has a history of derogative or, at least restrictive, meanings. Traditionally "women's writing" represented women's experience, as defined by men. Immanuel Roidis' discussion of women's writing at the turn of the century makes this very clear; women's writing should be,

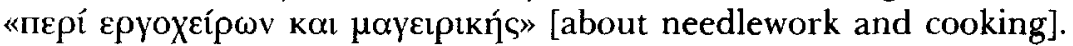
When women's writing ventured into the public sphere Roidis derided

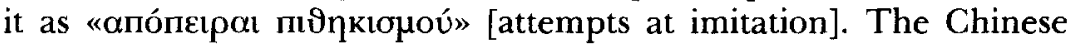
saying he quotes makes his position clear: «'A $\mu \alpha \eta$ ópvı $\theta \alpha \alpha \rho \chi^{\prime} \sigma \eta \eta$

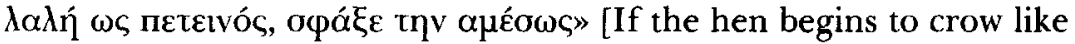
a cock kill her immediately] ) 1913: 85). ${ }^{3}$ Women in the private sphere were meant to keep things running smoothly by reproducing sons and writing about domestic life, so that men in the public sphere could get on with what was oddly considered to be more originary, and less derivative, the task of production. Although Roidis was exaggeratedly anti-feminist, his views of women's writing have nonetheless influenced generations of women writers and may be one reason why poets like Mastoraki and Laina are still reticent to call themselves "women poets."

Because of its minor status reek women writers themselves deny the category "women's writing" any specificity. They respond facetiously or dismissively to questions about "women's writing." Jenny Mastoraki, for example, said in response to the question. "Do you write women's poetry?":

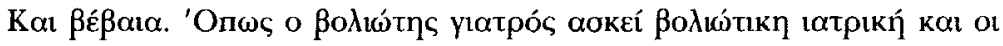

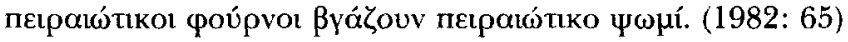

Of course. In so far as a doctor from Volos practices Voliot medicine and a bakery from Piraeus bakes Piraean bread.

This is a response which Laina has since quoted in response to similar questions.

Although women's poetry is no longer regarded as a ghetto of tender sentiments, and many critics even mention the importance of writing by women in the 1980s (Vitti 1987: 450; Maronitis 1987: 24), they still largely deny it its historical specificity. In a review of Mastoraki's Iotopís yı $\alpha \alpha$ B $\alpha \vartheta \imath \alpha$ [Tales of the Deep] (1983) and Laina's 


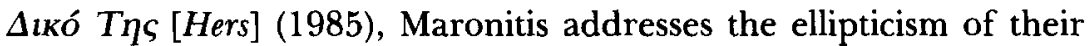
poetry, but fails to see what he calls their "visual narrative" as a writing strategy initiated under the dictatorship by many poets but sustained after the regime's fall by women poets in particular. For him the fact that both Mastoraki and Laina came up with a similar strategy is pure coincidence. He writes:

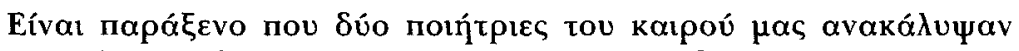

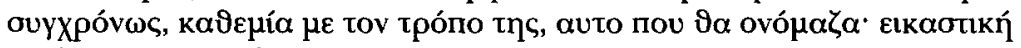

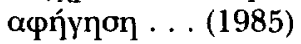

It's strange that two women poets of our times should discover simultaneously, each in their own way, what I shall call: visual narrative.

$\mathrm{He}$ is more concerned with individual talent than with the cultural logic of such a writing strategy for women poets. ${ }^{4}$

After the fall of the regime women poets continued to babble, employing the puns and double entendres characteristic of poetry written under censorship. The assumption was that power struggles, though perhaps more obvious under an authoritarian regime, did not disappear with a return to democracy. Numerous factors, but probably most important the rise of the women's movement (Stamiris 1986: 98-112), enabled women to make analogies between the status of the oppressed under a regime and the status of women more generally in Greek society. ${ }^{5}$ Whereas their male counterparts such as Lefteris Poulios and Vasilis Steriadis stopped writing or began repeating themselves, women poets of this generation sustained a poetics of censorship into the 1980s. The minor, deterritorialized status of women's writing had become empowering. Let us briefly examine two poetic styles which turn deterritorialization into an enabling writing strategy.

Mastoraki and Laina continue to a elaborate the missing connections and violence of censorship in their recent poetic narratives. In the terms of Deleuze and Guattari, Mastoraki's poetic narrative, Tales of the Deep, could be said to have a high coefficient of reterritorialization, containing too much detail, oversymbolizing so that each word has a multitude of meanings and it is impossible to tell which is the right one. Laina's Hers, on the other hand, foregrounds the process of deterritorialization, leaving out connections so that there is not enough meaning to go around, ultimately achieving a similar elliptical effect. Although many readers have lined up Mastoraki's and Laina's poetry on opposite sides of the tracks-Mastoraki's as excessive, baroque, even pedantic, and Laina's as minimalist, even simplistic-I find it more productive to see their respective excessive and minimalist responses as two expressions of deterritorialization in Greek women's 
poetry, similar to the way that Deleuze and Guattari view both reterritorialization in Meyrink and Brod and further deterritorialization in Kafka as two forms of deterritorialization in Jewish Literature.

The first poem of Laina's Hers begins by imitating the dry tone of an archeological description. But in contrast to the archaeological interest in what remains of an ancient wallpainting of a woman, the last line of the poem highlights her concern for what is missing. Linguistically and thematically the collection's project is set off from the archeologist's in the last line: their obsession with what is preserved"the beginning of the thighs ... the hair ribbon"-is trivial in the face of her conclusion: "the ground of love is missing."

Tolхоурафí

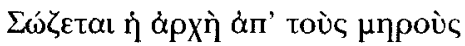

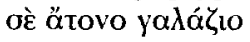

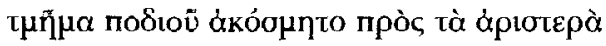

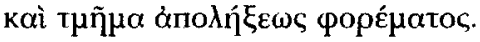

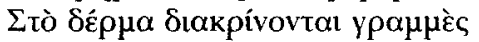

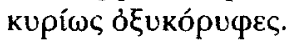

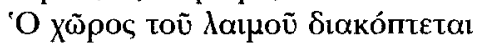
án' tòv á

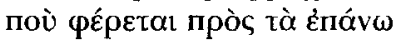

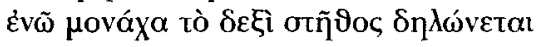

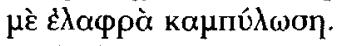
'Anò tò kó́t

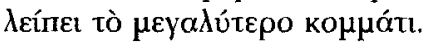

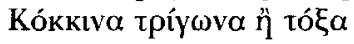

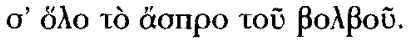

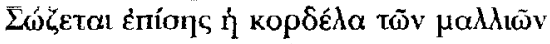

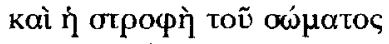

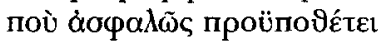

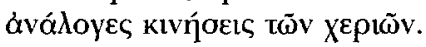

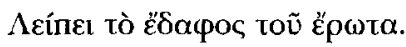

\section{Wallpainting}

The beginning of the thighs is preserved dull blue to the left an unadorned section of foot and a section from the end of the dress. Lines, mostly sharp angles are visible on the surface of the skin. The area around the neck is interrupted by the left arm 
which is raised up

while only the right breast is shown

by a slight curve.

Most of the lower part

of the face is missing.

Red triangles or arcs

spread over the whole white of the eye.

The hair ribbon is also preserved

and the twist of the body

which clearly presupposes

similar movements in the hands.

The ground of love is missing.

From page one Laina's poems address the fact that her place- $\Delta$ txó tᄁ $\varsigma$-is always elsewhere. The speaking subject like the writing itself is deterritorialized.

The poems that follow accentuate the sparseness and deterritorialized nature of Laina's style even further. Another example, one which I will come back to below when I discuss its translation, is indicative:

$\Delta \grave{\varepsilon} v \varepsilon \tilde{\varepsilon} v a l ~ \varepsilon ́ \delta \tilde{\omega}$

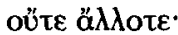

$\ddot{\alpha} \lambda \lambda \circ \tau \tilde{\mathrm{h}} \mathrm{tav}$

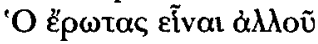

kaì uóvn țs

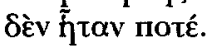

(1985: 14)

She is not here

nor was she

once upon a time;

once upon a time

she was.

Love is elsewhere

and never was

she alone.

The shifting of time and place is enacted here in the shifting word order. Everything is displaced and missing.

Mastoraki in her collection Tales of the Deep also has a poem about the way time disfigures woman, but her version, by recalling the event of her mutilation, reterritorializes woman rather than further deterritorializing her. The poem's language accentuates the bruised necks and crumpled petticoats that remain, not what is missing. 


\section{Toũ Kótw Kóopov}

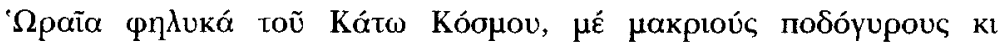

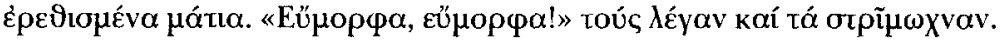

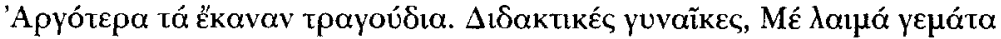

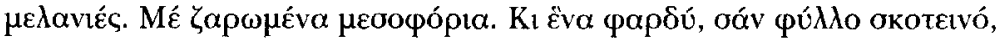
нат

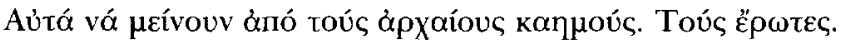

(1983: I6)

\section{Death Song}

Beautiful women of the Underworld, with long skirts and sore eyes. "Elegant, elegant!" they called them, cornering them. Later they turned them into songs. Exemplary ladies. With bruised necks. With crumpled petticoats. And something wide, like a dark leaf, staining their linen underwear.

Let that be what's left of ancient longing. And love affairs.

Instead of dwelling on what is missing, as Laina did-"the ground of love is missing"-Mastoraki redefines what remains - "Let that be what remains of ancient longing and love affairs." Both poetic narratives are preoccupied with the deterritorialized status of women and their writing but they structure this preoccupation in very different ways.

Greek women's reluctance to call their writing "women's writing" is perhaps more the result of an outmoded critical apparatus than a reflection of the contribution women have made to writing in the 1980s. No longer solely about needlework and cooking, women's writing since the dictatorship and the rise of the women's movement has become the terrain of an alternative writing which turned deterritorialization into an empowering place to write from. ${ }^{6}$ The resistance to the idea of women's writing seems left over from a time when women's writing was viewed as restrictive rather than liberating.

\section{Translation and Deterritorialization}

This case of empowering deterritorialization may be useful in a discussion of translation. Translations after all comprise deterritorialized, minor literatures within major languages. For centuries translators have sought to overcome this handicap in two opposing manners: on the one hand there are translators who believe that the translated poem should be a poem in its own right in the target language and should call attention to what is there; these translators seek to reterritorialize the poem in its new language. On the other hand there are those who believe the poem should always retain its foreignness and should call attention to what is missing; these transla- 
tors further deterritorialize the poem. ${ }^{7}$ If we keep in mind the way I have elaborated these terms with respect to Mastoraki's and Laina's poetry, it is possible to imagine that these two schools of translation are not as mutually exclusive as they often seem. Both are strategies for negotiating translation's deterritorialized status.

Like many women poets of the "Generation of 1970" Laina and Mastoraki earn their living as translators. Although it is often misleading to take the advice of poets when translating their poetry, Laina and Mastoraki provide interesting exceptions. Their advice corresponds in illuminating ways to their poetic projects: Laina rearticulates her "less than" deterritorializing poetics and Mastoraki, her "more than" reterritorializing poetics. For example, in a conversation Laina asked me to translate Hers in the same way she had written it:

... I want you to translate as if you had no emotion just like I tried to convince myself that I had no emotion when I wrote it ... I had written many beautiful lines in order to write this small book, you can imagine ... I didn't succeed immediately ... and in the effort, sometimes very beautiful poems would emerge-what they call "beautiful poems" ...which I left out . . . I wanted to leave them out . . I did not want emotion. (1987)

Here she speaks of estranging her readers, of cutting out that which they have come to expect. The translation, like Laina's own text, must not compensate, but further deterritorialize. Laina's and Mastoraki's different poetic expressions of deterritorialization suggest that no one theory or school of translation works all the time; some poems need deterritorializing and others reterritorializing and others some combination of the two.

Let us see how in translating the poetry of these two women poets of the same generation we must adopt very different strategies. In translating Laina's short simple phrases it soon becomes apparent that they sound flat unless further deterritorialized; they need to retain the foreigness of the Greek language. One solution is to retain the moveable syntax of Greek in English. I have done this in the second poem from Hers which I quoted. Although English snytax dictates the word order "and she was never alone" in the last line, in order to retain the deterritorialized feel of Laina's poem, I settled for a more scrambled order: "and never was she alone." In this way the reader can hear a foreign syntax in the English.

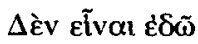

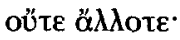

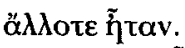

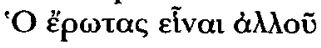




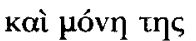

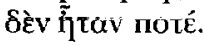

She is not here

nor was she

once upon a time;

once upon a time

she was.

Love is elsewhere

and never was

she alone.

On the other hand Mastoraki's poems flaunt different linguistic registers and are already foreign to themselves. Her poetry's thick symbolic structure needs to be reproduced in English. In one poem, which like the Laina poem above, addresses the deterritorialization of a woman, a woman on the run, the task of the translator is not to make the poem sound foreign, but to reterritorialize the rhythm of the fleeing horse in the English translation.

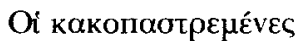

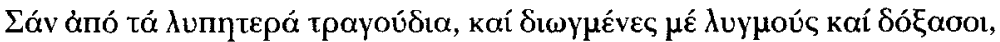

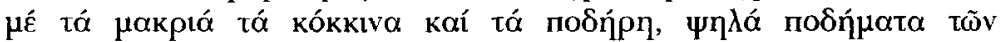

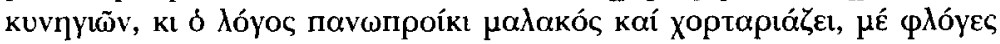

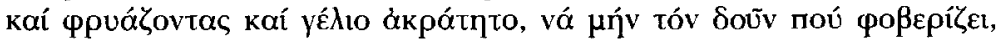
peúyouv-

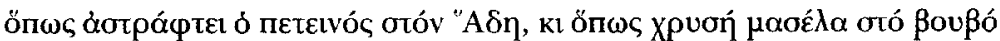

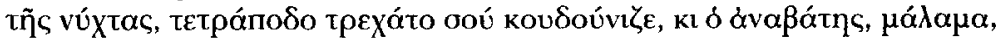

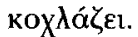

The Troubled Brides

As in sad ballads, chased by sobs and glorias, and gowns with long, red trains and tall hunting boots, and the soft promise of dowry overgrown with grass, and flames and fuming and unrestrained laughter, so that they don't see him threaten, they leave-

like the cock glistens in Hades, like a golden jaw in speechless night, a four-legged beast on the run wearing bells, and the rider bubbles up gold.

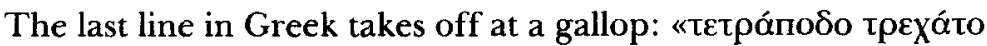

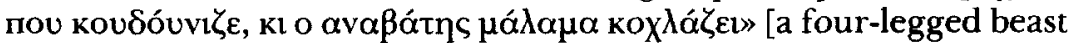
on the run wearing bells, and the rider bubbles up gold]. This de- 
territorialization is lost in deterritorialized, that is if the Greek word order is kept, and the phrase is made to sound jarring and foreign. Instead it demands an equivalent rhythm of a galloping horse in English. In the translation of both Laina's and Mastoraki's recent collections the high coefficient of deterritorialization can be retained, though very different processes are necessary to achieve this.

In conclusion, by thinking about translation with regard to and as deterritorialization I have tried to outline how two styles of poetry suggest the interconnectedness of two different translation practices. Such hands-on theory encourages us to reject the possibility of one master theory of translation and instead pose local solutions. An appreciation of the specific styles of "babble" of recent women's poetry in Greece can make us more receptive to the "Babel" of translation theories available today.

Columbia University

\section{NOTES}

Acknowledgments. I would like to thank Nelson Moe for his comments on this article.

${ }^{1}$ Throughout this piece I will be referring to definitions of deterritorialization, reterritorialization and minor literature which I have outlined in my introduction. Although I borrow these terms from Deleuze and Guattari (1986), these terms will be altered considerably when we view them in the context of women's poetry in Greece after the dictatorship.

${ }^{2}$ For an overview of these theories see Jacques Derrida's "Des Tours de Babel" (Derrida 1985: 165-248).

${ }^{9}$ For an interesting discussion of Roidis and of the Ladies' Journal he is attacking here see that of Eleni Varika (1987: 16, 193-194).

"In his recent essay on the poets of the "Generation of 1970 " he is careful to distinguish the cultural specificity of their project, so this lapse when it comes to describing two women poets of this generation is revealing. Even when he mentions the wealth of good women poets in this more carefully argued article, he still resists any attempt to analyze their project separately (1987: 241).

${ }^{5}$ For an interesting comparison see Janet Hart's Ph.D. Thesis "Empowerment and Political Opportunity: Greek Women in Resistance, 1941-44" which outlines women's political empowerment through the larger social movement of the resistance. Whereas in the 1940s mobilized women were expected to return home after the war, after the fall of the dictatorship in 1974 mobilized women maintained and increased their presence in the public sphere.

${ }^{6}$ It is interesting to note that most American and German women writers consider the term "women's writing" an empowering distinction whereas French, Soviet, Italian 
and Greek, usually do not. (Though French literary theorists may champion écriture feminine the women writers in France resist this category.) It is important to remember that "women's writing" did not become an empowering term in America until the 1960s and in Germany until the 1970s with the rise of the women's movement in each country. Suddenly women's experience was seen as new, uncharted territory. Although everyone knew what men felt, since Western literature was predominantly what men felt, no one knew what women felt. It was not only that women could talk about ironing, and men about hunting, but that their whole stmucture of feeling, as Raymond Williams would say, was different, and that this difference was suddenly valued.

'See Elizabeth Constantinides' discussion of translation and her first footnote in this issue where she outlines these two schools.

\section{REFERENCES CITED}

Deleuze, Gilles and Félix Guattari

1986 Kafka. Towards a Minor Literature. Translated by Dana Polan. Minneapolis: Liniversity of Minnesota Press.

Derrida, Jacques

1985 Des Tour de Babel. In Difference in Translation, edited by Joseph F. Graham. Ithaca: Cornell University Press.

Hart, Janet

1989 Empowerment and Political Opportunity: Greek Women in Resistance, 1941-44. Ph.D. Dissertation. Cornell University.

Laina, Maria

1985 Aıxó tnc. Athens: Keimena.

1987 Personal interview (18 September). Athens.

Maronitis, D. N.

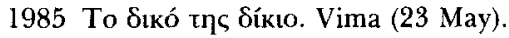

1987 Métpı $\alpha$ kå Mıкр́́. Athens: Kedros.

Mastoraki, Jenny

1982 Interview. Diavazo 50: 64-65.

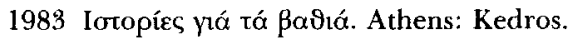

Roidis, Immanuel

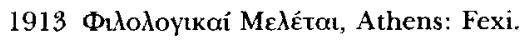

Stamiris, Eleni

1986 The Women's Movement in Greece. New Left Review 158: 98-112.

Van Dyck, Karen

1990 The Poetics of Censorship in Greece since 1967. Ph.D. Dissertation. University of Oxford.

Varika, Eleni

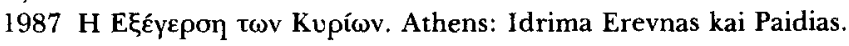

Vitti, Mario

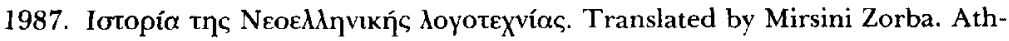
ens: Odysseas. 